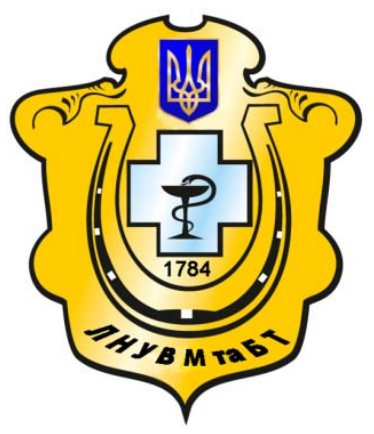

Науковий вісник Львівського національного університету ветеринарної медицини та біотехнологій імені С.3. Гжицького

Scientific Messenger of Lviv National University of Veterinary Medicine and Biotechnologies named after S.Z. Gzhytskyj

doi:10.15421/nvlvet7120

ISSN 2413-5550 print

ISSN 2518-1327 online

$\underline{\text { http://nvlvet.com.ua/ }}$

УДК 6363:637:636.087.6

\title{
Вміст важких металів у кормах, організмі тварин та продукції тваринництва в агроекологічних умовах Закарпаття
}

\author{
Р.Г. Сачко, Я.В. Лесик, І.В. Лучка, І.В. Невоструєва \\ romans-34@i.ua \\ Інститут біології тварин НААН, \\ вул. В. Стуса, 38, м. Львів, 79034, Україна
}

\begin{abstract}
Вивчали вміст Кадмію, Свинцю, Стронщію та Нікелю у біологічній системі: довкілля-корми-тваринатваринницька продукиія в агроекологічних умовах Закарпаття. Відзначено, щзо вміст Кадмію та Стронцію у зразках трунту, відібраних з господарських угідь ПСП «Ласточка», Ужгородського району, Закарпатської області не перевищував гранично допустимих концентрацій, тоді як рівень Свинцю і Нікелю був вищим. Вміст досліджуваних елементів у воді, якою напували корів господарства, становив від 0,02 мг/л до 1,02 мг/л і не перевищував гранично допустимих концентрачій, що відповідає чинним ветеринарно-санітарним вимогам. 3 літературних джерел відомо про залежність між рівнем важких металів у трунті та накопиченням їх в сільськогосподарських культурах. Одержані результати дослідження вмісту важких металів у кормах (сіно, солома пшенична, комбікорм), заготовлених у господарстві, не перевищували гранично допустимих концентрацій досліджуваних елементів у кормах рачіону для тварин. Відомо, щчо важкі метали $з$ кормів трансформуються в організм тварин і впливають на інтенсивність метаболічних прочесів, фізіолого-біохімічний стан та продуктивні якості тварин. Концентрація досліджуваних елементів у иільній крові та шерсті корів була у межах фізіологічних величин. Абсолютний вміст Кадмію, Свинцю, Стронцію та Нікелю, у молоці дослідних корів, відповідно, становив 0,014; 0,02; 0,15 і 0,2 мг/кг і не перевищував гранично допустимих концентрачій.

Аналіз коеріиієнтів кореляції між вмістом ВМ у біологічній системі: довкілля-корми-тварина-тваринницька продукиія показав сильний корелячійний зв'язок між вмістом ВМ у трунті й воді і таких кормах, як солома та комбікорм, та в крові і шерсті тварин і молоці, а також слабий зв'язок між їх вмістом у ланцюгу: вода - сіно - кров - молоко.

Ключові слова: важкі метали, гранично допустимі концентрації, довкілля, трунт, вода, корми, велика рогата худоба, продукиія тваринництва, біогеохімічна провінція.
\end{abstract}

\section{Содержание тяжелых металлов в кормах, организме животных и продукции животноводства в биогеохимической провинции Закарпатья}

\author{
Р.Г. Сачко, Я.В. Лесик, И.В. Лучка, И.В. Невоструева \\ romans-34@i.ua
}

Институт биологии животных НААН,

ул. В. Стуса, 38, г. Львов, 79034, Украина

\begin{abstract}
Изучали содержание Кадмия, Свинцฺа, Стронция и Никеля в биологической системе: окружающая среда-кормаживотное - продукиия животноводства в агроэкологических условиях Закарпатья. Отмечено, что содержание Кадмия и Стронция в образцах почвы, взятых с сельскохозяйственных угодий ЧСП «Ласточка», Ужгородского района, Закарпатской области не превымало предельно допустимых концентраций, тогда как уровень Свиниа и Никеля был выше. Содержание исследуемых элементов в воде, которой поили коров хозяйства, составил от 0,02 мг/л до 1,02 мг/л и не превыиал предельно допустимых концентраций, что соответствует действуюшим ветеринарно-санитарным требованиям. Из литературных источников известно о зависимости между уровнем тяжельх металлов в почве и их накоплением в сельскохозяйственных культурах. Полученные результаты исследования концентрации тяжельх металлов у кормах (сено, пшенич-
\end{abstract}

Citation:

Sachko, R.G., Lesyk, Ja.V., Luchka, I.V., Nevostruyeva, I.V. (2016). Contents of heavy metals in food, organism and animal products in the Zacarpathian biogeochemical province. Scientific Messenger LNUVMBT named after S.Z. Gzhytskyj, 18, 3(71), 87-90. 
ная солома, комбикорм), которые были заготовлены в хозяйстве не превышали предельно допустимых кониентраиий исследуемых элементов у кормах рациона для животных. Известно, что тяжелье металль с кормов трансформируются в организм животных и влияют на интенсивность метаболических процессов, физиолого-биохимическое состояние и продуктивные качества животных. Концентрация исследуемых элементов цельной крови и шерсти коров была в границах физиологических величин. Абсолютное содержание Кадмия, Свиниа, Стронция и Никеля в молоке исследуемьх коров соответственно было 0,014; 0,02; 0,15 и 0,2 мг/кг и не превымало предельно допустимых концентраций.

Анализ коэффициентов корреляции содержания тяжёлых металлов у биологической системе: окружающая средакорма-животное - продукция животноводства показал сильную корреляционую связь между содержанием тяжёльх металлов воде, почве и таких кормах как солома, комбикорм, а также в крови и шерсти животных молоке. Также слабую связь обнаружено между их содержанием в цеепоче: вода - сено - кровь -молоко.

Ключевые слова: тяжелье металль, предельно допустимые концентрачии, окружающая среда, почва, вода, корм, крупныцй рогатый скот, продукция животноводства, биогеохимическая провиничя.

\title{
Contents of heavy metals in food, organism and animal products in the Zacarpathian biogeochemical province
}

\author{
R.G. Sachko, Ja.V. Lesyk, I.V. Luchka, I.V. Nevostruyeva \\ romans-34@i.ua
}

Institute of Animal Biology NAAS, V. Stus Str., 38, Lviv, 79034, Ukraine

\begin{abstract}
We studied the content of Cadmium, Lead, Strontium and Nickel in the biological systems: environment - feed - animal - livestock products in agroecological conditions of Zacarpathian region. It is noted that the content of Cadmium and Strontium in soil samples taken from commercial land PAL "Lastochka», Uzhgorod district, Zacarpathian region did not exceed the maximum allowable concentrations, whereas the levels of Lead and Nickel were higher. The content of investigated elements in water used for watering cows in farm was 0.02-1.02 $\mathrm{mg} / \mathrm{l}$ and did not exceed the maximum allowable concentrations which is up to veterinary and sanitary requirements. It is known from the literary sources that there is interdependency between the heavy metals level in soil and their accumulation in farming cultures. The obtained results of the study of heavy metals in feed (hay, straw, wheat, mixed fodder) harvested on the farm did not exceed the maximum allowable concentrations of studied elements in feed rations for animals. It is known that heavy metals in fodder transform in animal organism and have influence on the intensity of metabolic processes, physiological and biochemical condition and animal productivity. Concentrations of the elements in cows' whole blood and hair were within physiological values. Absolute content of Cadmium, Lead, Strontium and Nickel in the milk of studied cows were under 0.014; 0.02; 0.15 and $0.2 \mathrm{mg} / \mathrm{kg}$, respectively and did not exceed the maximum allowable concentrations.

The analysis of coefficient of correlation between the heavy metals content in biological systems: environment-feed - animal livestock products revealed the strong correlation between the heavy metals content in soil and water, in straw and mixed fodder, in blood, hair and milk, and the poorly expressed correlation between their content in catena: water-straw - blood-milk.
\end{abstract}

Key words: heavy metals, maximum allowable concentration, environment, soil, water, fodder, cattle, livestock products, biogeochemical province.

\section{Вступ}

Зростання антропогенного впливу на екосистеми призвело до забруднення довкілля важкими металами (BM), що ставить перед світовою наукою низку важливих проблем щодо запобігання розповсюдженню, накопиченню та контроль за їх вмістом у грунті, воді, кормах, організмі тварин та продукції тваринництва (Bohatyrev, 2003; Haletskyi and Ehorova, 2008). Серед токсичних речовин, які акумулюються у різних ланках трофічного ланцюга наземних і водних екосистем найнебезпечнішими є ВМ, які надходять із викидами автотранспорту, відходами промисловості та сільського господарства, при використанні агрохімікатів і мінеральних добрив (Velychko, 2007). Грунт інтенсивно акумулює важкі метали, поглинає і зберігає їx, тому довготривале і систематичне внесення добрив i отрутохімікатів може підвищити їхню концентрацію. Відомо, що найвищий вміст Кадмію міститься у фосфорних добривах (від 0,02 до 10 мг/кг). Максимально допустиме надходження $\mathrm{Cd}$ у грунт за нормами Свропейських країн становить 4 г/кг в рік. У результаті надходження $\mathrm{Cd}$ з кормами в організм тварин уражаються нирки, порушується синтез білка і баланс віта- мінів. Кадмій пригнічує фосфорно-кальцієвий обмін, а також впливає на метаболізм деяких мікроелементів (Hordiienko et al., 2006; Kravtsiv and Butsiak, 2008).

ВМ відносяться до небезпечних забруднювачів довкілля, які через токсичний стрес спричиняють різноманітні порушення функціонального стану організму тварин і людей. Потрапляючи в організм у невеликих дозах, протягом тривалого часу, і накопичуючись в різних органах і тканинах, ВМ можуть викликати токсикози, які супроводжуються порушеннями біохімічних процесів, структури і функції клітин, зокрема проникності останніх для хімічних компонентів внутрішнього середовища (Kessels et al., 1990; Beyersmann and Hechtenberg, 1997).

Доведено, що вміст Свинцю і Кадмію у внутрішніх органах і м'язах тварин при використанні кормів 3 індустріально розвинутих регіонів у декілька разів перевищував їх рівень, ніж у тварин 3 екологічно безпечних зон. 3 даних літератури відомо, що корми $\epsilon$ основним джерелом надходження в організм тварин ВМ і можуть сягати до 99 \% від їх загальної кількості. (Litwinczuk et al., 1999; Fedoruk and Kovalchuk, 2007).

Беручи до уваги широкий спектр біологічної і токсичної дії ВМ, яка спричиняє зниження здатності до 
відтворення, збереженості та продуктивності тварин (Hetmanska, 1994; Sachko et al., 2013), заслуговує на увагу необхідність проведення моніторингу визначення їхнього вмісту у біологічній системі: довкілля корми - тварина-продукція тварин у різних біогеохімічних провінціях України. Виходячи із вище наведеного метою наших досліджень було вивчити вміст $\mathrm{Cd}, \mathrm{Pb}, \mathrm{Sr}, \mathrm{Ni}$ у грунті, воді, кормах, та з'ясувати їхню трансформацію в організмі тварин та продукцію тваринництва в агроекологічних умовах Закарпаття.

\section{Матеріал і методи досліджень}

Дослідження проводили у ПСП «Ласточка» Ужгородського району, в агроекологічних умовах Закарпаття. Для проведення досліду сформували групу 310 корів чорно-рябої породи, які були аналогами за віком, продуктивністю, фізіологічним станом і утримувалися на збалансованому раціоні за встановленими нормами годівлі.

Вміст ВМ: Кадмій (Cd), Свинець (Pb), Стронцій (Sr), Нікель (Ni) визначали атомно-абсорбційним методом на спектрофотометрі C-115 ПК. Для досліджень брали зразки грунту, води, кормів раціону (сіно, солома, комбікорм), а від корів брали цільну кров, зразки шерсті - $з$ ділянки холки та молоко.

Грунт відбирали за методикою відбору грунтів згідно 3 ДСТУ 4287:2004. Для дослідження вмісту важких металів зразки грунту мінералізували методом сорбції, а корми, кров, молоко та шерсть - методом сухого озолення, згідно з ДСТУ 26929-94. Одержані цифрові дані обробляли статистично за допомогою методу варіаційної статистики.

\section{Результати та їх обговорення}

У зразках грунту, відібраних для досліджень 3 господарських угідь ПСП «Ласточка», розміщеного в агроекологічній провінції Закарпаття вміст Кадмію та Стронцію не перевищував гранично допустимих концентрацій (ГДК) (табл. 1). Встановлено, що абсолютний вміст Свинцю у грунті перевищував ГДК який становить $(6,0$ мг/кг). Концентрація Нікелю у декілька разів була вищою від ГДК (4,0 мг/кг), що може свідчити про його кумуляцію у верхніх шарах грунту в результаті техногенного забруднення. На показники вмісту Свинцю та Нікелю у грунті можуть впливати розміщені близько до сільськогосподарських угідь промислові підприємства і міжнародна автомагістраль. Вміст важких металів у воді, якою напували корів, був в межах ГДК від 0,02 до 1,02 мг/кг.і відповідав ветеринарно-санітарним вимогам до питної води для тварин. У наукових працях низки авторів (Величко В. О., 2007; Федорук Р.С., 2008; Кравців Р.Й., 2008) показано, що між рівнем рухомих форм іонів ВМ у грунті та накопиченням їх у сільськогосподарських культурах існує пропорційна залежність. Дослідженнями впливу ВМ у системі грунт - рослина встановлено, що забруднені ксенобіотиками грунти, у концентраціях, що перевищують ГДК, спричиняють значну кумуляцію їх у сільськогосподарських рослинах. Концентрація $\mathrm{Cd}$ у сіні, соломі та комбікормі становила, відповідно, 0,33; 0,21, 0,33 мг/кг і не перевищувала ГДК цього елемента у раціоні. Абсолютний вміст Свинцю у кормах, що заготовлені у господарстві не перевищував ГДК (5,0 мг/кг). Показники вмісту Нікелю у заготовлених кормах в ПСП «Ласточка» не перевищували допустимих концентрацій (3,0 мг/кг сухого корму). Одержані результати вмісту Стронцію у сіні, соломі та комбікормі були вищими від гранично допустимих концентрацій (ГДК 0,4 мг/кг корму). За даними літератури відомо, що ВМ 3 кормів раціону трансформуються в організм тварин та впливають на інтенсивність метаболічних процесів, фізіологобіохімічний стан та продуктивні якості тварин. За даними наших досліджень вміст $\mathrm{Cd}, \mathrm{Pb}, \mathrm{Sr}, \mathrm{Ni}$ у крові корів, що утримуються в агроекологічних умовах Закарпаття не перевищував фізіологічних величин (0,014; 0,03; 0,21; 0,27 мг/кг) відповідно. Встановлено, що вміст ВМ у молоці корів $\mathrm{Cd}-0,014$ мг/кг; $\mathrm{Pb}-$ 0,02 мг/кг; $\mathrm{Sr}-0,15$ мг/кг; Ni - 0,2 мг/кг 3 господарства ПСП «Ласточка» не перевищував МДР. Наведені в таблиці результати досліджень вмісту ВМ у шерсті корів, яка $є$ показником їх накопичення та трансформації до організму впродовж тривалого періоду показали, що вміст $\mathrm{Cd}, \mathrm{Pb}, \mathrm{Sr}, \mathrm{Ni}$ у зразках шерсті становив 0,$32 ; 0,87 ; 1,18 ; 1,30$ мг/кг відповідно і не перевищував МДК.

Таблиця 1

Вміст важких металів у досліджуваних зразках, $(\mathrm{M} \pm \mathbf{m}, \mathbf{n}=10)$

\begin{tabular}{|l|c|c|c|c|}
\hline \multirow{2}{*}{ Матеріал для досліджень } & \multicolumn{3}{c|}{ Важкі метали } \\
\cline { 2 - 5 } & $\mathrm{Cd}$ & $\mathrm{Pb}$ & $\mathrm{Sr}$ & $\mathrm{Ni}$ \\
\hline Грунт, мг/кг & $0,47 \pm 0,04$ & $6,34 \pm 0,96$ & $1,17 \pm 0,04$ & $23,87 \pm 2,14$ \\
\hline Вода, мг/л & $0,02 \pm 0,003$ & $0,03 \pm 0,004$ & $0,52 \pm 0,02$ & $1,02 \pm 0,05$ \\
\hline Сіно лугове, мг/кг & $0,33 \pm 0,02$ & $1,028 \pm 0,08$ & $0,49 \pm 0,05$ & $1,11 \pm 0,06$ \\
\hline Солома пшенична, мг/кг & $0,21 \pm 0,02$ & $0,56 \pm 0,06$ & $0,63 \pm 0,04$ & $1,29 \pm 0,09$ \\
\hline Комбікорм, мг/кг & $0,33 \pm 0,03$ & $0,75 \pm 0,07$ & $0,48 \pm 0,03$ & $1,57 \pm 0,12$ \\
\hline Кров, мг/л & $0,014 \pm 0,002$ & $0,03 \pm 0,002$ & $0,21 \pm 0,03$ & $0,27 \pm 0,03$ \\
\hline Молоко, мг/л & $0,014 \pm 0,003$ & $0,02 \pm 0,002$ & $0,15 \pm 0,02$ & $0,20 \pm 0,04$ \\
\hline Шерсть, мг/кг & $0,32 \pm 0,03$ & $0,87 \pm 0,06$ & $1,18 \pm 0,05$ & $1,30 \pm 0,11$ \\
\hline
\end{tabular}

Проведений нами кореляційний аналіз отриманих результатів (табл. 2) зв'язок між вмістом ВМ у навколишньому середовищі (вода, грунт) та кормами (сіносолома-комбікорм), що коливався по силі зв’язку у межах 0,8-0,93, за винятком вода-сіно, який становив 0,45 .

Що стосується кореляційних зв'язків між вмістом важких металів у системі воді-солома-комбікорм та 
організмі тварин (кров, шерсть), то нами також встановлений сильний кореляційний зв'язок на рівні $0,72-0,98$, що характеризує високий ступінь трансформації ВМ із води та корму у шерсть тварин. Слід відмітити нижчу трансформацію ВМ із сіна, що споживали, у кров тварин, коефіцієнт кореляції у даному випадку становив 0,22. Що стосується кореляційних зв'язків між вмістом ВМ у воді та кормах (солома, комбікорм), що споживали тварин та їх вмістом у молоці то відмічено також сильні зв'язки на рівні $0,68-0,98$, що свідчить про високий ступінь трансформації цих сполук у молоко і порівняно нижчий ступінь трансформації із сіна у молоко, коефіцієнт кореляції становив 0,34 .

Кореляційні зв'язки між вмістом важких металів у досліджуваних зразках

\begin{tabular}{|l|c|c|c|c|c|c|c|c|}
\hline & Грунт & Вода & $\begin{array}{c}\text { Сіно } \\
\text { лугове }\end{array}$ & $\begin{array}{c}\text { Солома } \\
\text { пшенична }\end{array}$ & Комбікорм & Кров & Молоко & Шерсть \\
\hline Грунт & - & 0,80 & 0,80 & 0,93 & - & - & - & - \\
\hline Вода & 0,80 & - & 0,45 & 0,92 & - & 0,90 & 0,98 & 0,72 \\
\hline Сіно лугове & 0,80 & 0,45 & - & - & - & 0,22 & 0,34 & 0,93 \\
\hline Солома пшенична & 0,93 & 0,92 & - & - & - & 0,75 & 0,86 & 0,92 \\
\hline Комбікорм & - & - & - & - & - & 0,52 & 0,68 & 0,98 \\
\hline Кров & - & 0,90 & 0,22 & 0,75 & 0,52 & - & 0,98 & 0,45 \\
\hline Молоко & - & 0,98 & 0,34 & 0,86 & 0,68 & 0,98 & - & 0,59 \\
\hline Шерсть & - & 0,72 & 0,93 & 0,9243 & 0,98 & 0,45 & 0,59 & - \\
\hline
\end{tabular}

\section{Висновки}

Вміст Свинцю та Нікелю у грунтах, взятих для досліджень $з$ господарських угідь ПСП «Ласточка», перевищував ГДК. Встановлена пропорційна залежність між вмістом ВМ у сільськогосподарських культурах та їх концентрацією у біологічному матеріалі. В агроекологічних умовах Закарпаття вміст досліджуваних $\mathrm{BM}(\mathrm{Cd}, \mathrm{Pb}, \mathrm{Sr}$, та $\mathrm{Ni})$ в шерсті корів не перевищував ГДК.

Перспективи подальших досліджень. Моніторинг BM у системі довкілля-корми-тварина-тваринна продукція та розроблення комплексу агроекологічних заходів щодо зменшення негативного впливу важких металів на обмін речовин в організмі продуктивних тварин та їхній продукції.

\section{Бібліографічні посилання}

Bohatyrev, A.N. (2003). O proyzvodstve эkolohychesky bezopasnoi pyshchevoi produktsyy. Molochnaia promyshlennost. 2, 17-19 (in Russian).

Haletskyi, L.S., Ehorova, T.M. (2008). Rehionalnyi ekoloho-heokhymycheskyi analyz vlyianyia tiazhelykh metallov promyshlennykh otkhodov na sostoianye okruzhaiushchei sredy Ukrainy / L. S. Haletskyi, // Naukovo-tekhnichnyi zhurnal «Ekolohiia dovkillia ta bezpeka zhyttiediialnosti». 5, 10-15 (in Russian).

Velychko, V.O. (2007). Fiziolohichnyi stan orhanizmu tvaryn, biolohichna tsinnist moloka i yalovychyny ta yikh korektsiia za riznykh ekolohichnykh umov seredovyshcha. Lviv (in Ukrainian).

Hordiienko, O.A., Kostyk, Ya.I., Surovtseva, O.V., Shvets, S.M., Zastavna, O.V. (2006). Otsinka ekolohichnoho stanu gruntiv za vmistom vazhkykh metaliv. I-y Vseukrainskyi zizd ekolohiv: mizhnar. nauk.-tekhn. konf., 4-7 zhovtnia, 247 (in Ukrainian).

Kravtsiv, R.Y., Butsiak, H.A. (2008). Sumisnyi vplyv vazhkykh metaliv na orhanzim tvaryn. Naukovyi visnyk LNUVMBT imeni S. Z. Hzhytskoho. 10, 2(37), 3-8 (in Ukrainian).

Kessels, B.G., Wensing, T., Wentink, G. (1990). Clinical, chemical and hematological parameters in cattle kept in a cadmium contaminated area. Bulletin of Environmental Contamination \& Toxicology. 44(2), 339344.

Beyersmann, D., Hechtenberg, S. (1997). Cadmium Gene Regulation and Cellular Signalling in Mammalian Cell. Toxicology and Applied Pharmacology, 47-61.

Litwinczuk, A., Drozd-Janczak, A., Florek, M. (1999). Zawartosc Metali ciezkich ( $\mathrm{Pb}$ I Cd) w mleku towarowym produkowanym w rejonach premyslowych I typowo rolniczych. Roczniki naukowe zootechniki. Annals of Animal Science. Institut zootechniki. Krakow. 26(I), 219-228.

Fedoruk, R.S., Kovalchuk, I.I. (2007). Biolohichna tsinnist i yakist moloka $\mathrm{v}$ konteksti tekhnohennoho zabrudnennia pryrodnoho seredovyshcha ta ekolohichnoi bezpeky. Biolohiia tvaryn. 9(1-2), 1019 (in Ukrainian).

Sachko, R.H., $\quad$ Lesyk, Ya.V., $\quad$ Pylypets A.Z., Hrabovska O.S. (2013). Vmist vazhkykh metaliv u hrunti, kormakh ta biolohichnomu materiali $\mathrm{v}$ ahroekolohichnykh umovakh Lisostepu ta Polissia. Naukovyi visnyk Lvivskoho natsionalnoho universytetu veterynarnoi medytsyny ta biotekhnolohii im. S. Z. Gzhytskoho. 15(3), 415-421 (in Ukrainian).

Hetmanska, B. (1994). The metal-metal interactions in biological systems. Water, air and Soil Pollut. 74(34), 281-288.

Стаття надійшла до редакиії 1.09.2016 